\title{
Avaliação in Vitro da Atividade Antibacteriana de Diferentes Própolis
}

\author{
Denyse Moraes Jardim (I), Keily Alves de Moura Oliveira (I), Glauco \\ Vieira Oliveira (I) \\ (I) UFMT - Universidade Federal do Mato Grosso (Rua Senador Valdon Varjão, 6390, Setor \\ Druys, CEP 78600-000, Barra do Garças-MT)
}

\section{Resumo}

A própolis, um produto resinoso coletado por abelhas, de diferentes exsudados vegetais, é útil na manutenção e segurança da colmeia. Essa substância tem despertado o interesse de muitos pesquisadores devido às suas inúmeras propriedades terapêuticas, tais como anti-inflamatória, cicatrizante, antioxidante, antimicrobiana, anestésica, anticancerígena, dentre outras. Vários relatos bibliográficos mostram que os diversos tipos de extratos de própolis possuem acentuada ação inibidora, in vitro, sobre bactérias do gênero Gram negativo, em menor escala, sobre as bactérias do gênero Gram positivo. Neste trabalho, objetivou-se produzir o extrato hidroalcoólico de três tipos de própolis, Verde, Marrom e Vermelha, e avaliar sua atividade antibacteriana frente as cepas de Staphylococcus aureus e Escherichia coli. A produção dos extratos das própolis foi produzindo macerando-se $30 \mathrm{~g}$ de própolis e misturando-a em $100 \mathrm{~mL}$ de álcool de cereais a $80 \%$, e essa solução foi extraída através do misturador tipo "shake" por 3 horas a $50^{\circ} \mathrm{C}$. $\mathrm{Na}$ análise de identificação da atividade antibacteriana, foram utilizados discos estéreis, onde foram aplicados $20 \mu \mathrm{L}$ dos extratos de própolis. Os discos que foram utilizados como controle foram obtidos pela aplicação de uma solução hidroalcoólica. O teste de sensibilidade foi realizado de acordo com o método de BAUER et al. (1966). O controle para os patógenos foi feito com o antibiótico cloranfenicol. A atividade antibacteriana foi determinada pela formação ou não de halo inibitório ao redor dos discos. Notou-se que a própolis possui

\footnotetext{
Referência:

Denyse Moraes Jardim, Keily Alves de Moura Oliveira, Glauco Vieira Oliveira. Avaliação in Vitro da Atividade Antibacteriana de Diferentes Própolis. In: Anais do 12 Congresso Latinoamericano de Microbiologia e Higiene de Alimentos - MICROAL 2014 [= Blucher Food Science Proceedings, num.1, vol.1]. São Paulo: Editora Blucher, 2014.

DOI 10.5151/foodsci-microal-274
} 
efeito inibitório frente a S. aureus, não apresentando o mesmo resultado em E. coli, sendo sendo que o melhor resultado, avaliado pela medição do halo de inibição formado, foi o do extrato de própolis Verde, seguido da Vermelha e Marrom. A menor sensibilidade das Gram negativas deve-se provavelmente as diferenças na constituição química da parede celular destas bactérias. Logo, concluiu-se que os Extratos de Própolis possuem ação antibacteriana frente à cepas de $\mathrm{S}$. aureus.

Palavras-Chave: Antibacteriana, Própolis, E. coli, S. aureus Agência de Fomento: CNPQ 